\title{
PENERAPAN SISTEM INFORMASI MANAJEMEN UNTUK PEMBUATAN JADWAL INDUK PRODUKSI DENGAN METODE LINIER PROGRAMMING
}

\author{
Lailis Syafaah *)
}

\begin{abstract}
Generally, factories always want to give bidden to consumer, therefore need the best production of plain and schedule by programming linier method in order that can be effective and efficient. Reality main problem from PT. Serasa Purna Cipta Sidoarjo was pile up of sort product and little others product to next times and to threaten to the first skripsi about difficulty of factories to make QS program for actuality production of excellent schedule. Therefore how to actuality management of information system in order that process preparation data in the factories was not difficultly for the actuality. The meaning for based on and experience last time, the factories to do that program was difficultly to program operation so production of excellent schedule realize difficulty. To that answer need actually Management of information system for production of excellent schedule to every group product to every period.

To composite management of information system to production planning by programming linear method, the first ways is fortune telling of bidden to suppose bid quantity to next period by weighted moving average method, Double exponential smoothing, exponential smoothing with linear trend, linear regression, moving average with linear trend, simple exponential smoothing, double exponential smoothing with linear trend. And then searching smaller MAPE. For next ways is manual formulation by programming linear method contents finally variable, direction function and boundary variable. After that making program to management of information system by new Visual Basic program even if to seeing aggregate planner to produce production of excellent schedule.

From that account can be knower was all bidden can realization and direction can realize too with cost production minimize at Rp. 662.887 .110 from factories step target was cost production minimize at Rp. 680.590 .700 .
\end{abstract}

Keywords: Probability, programming linear formulation, management of information system, aggregate, production of excellent schedule

\section{A. PENDAHULUAN}

Pada saat ini jika keputusan dapat didasarkan pada kebijaksanaan, prosedur atau ketentuan maka keputusan itu dapat diprogram untuk aplikasi komputer, sehingga akan menimbulkan potensi operasi yang lebih cepat, tepat, akurat dan ekonomis. Dari hal tersebut dapat dilihat bahwa peranan komputer dalam era informasi yang praktis ini sangat dibutuhkan dalam penanganan pengolahan data dalam jumlah yang besar yang dihubungkan dengan penyimpanan, pengolahan dan pengambilan kembali informasi tersebut. Jadwal induk produksi yang kurang baik menyebabkan tidak meratanya beban kerja yang diterima karyawan tiap harinya. Ketika permintaan menurun, proses produksi yang berkurang, sehingga banyak karyawan yang menganggur. Disaat lain, dimana permintaan meningkat, perusahaan terpaksa memberlakukan lembur yang seharusnya dapat dibebankan pada saat waktu reguler yang kosong pada periode sebelumnya. Selain itu beban kerja yang berat pada saat lembur dapat mengurangi produktifitas tenaga kerja, sehingga jam lembur perlu diminimumkan.

PT. Serasa Purna Cipta adalah perusahaan yang bergerak dibidang Glass Processing di Sidoarjo. Perusahaan ini memproduksi berbagai jenis kaca

\footnotetext{
*) Dosen Fakultas Teknik Universitas Muhammadiyah Malang
} 
yang terdiri dari berbagai macam komponen. Dimana dalam kinerjanya dihadapkan pada kenyataan penumpukan suatu jenis produk dan kekurangan produk lain pada suatu waktu. Hal ini disebabkan segala perencanaan dan penjadwalan produksi hanya didasarkan pada pengalaman masa lalu dan intuisi saja. Hal ini dapat mengakibatkan kerugian bagi perusahaan untuk memperoleh laba seoptimal mungkin belum dapat terpenuhi.

\section{Tujuan}

Adapun tujuan pemecahan masalah adalah sebagai berikut :

1. Menyusun rencana produksi dengan menggunakan metode Linear Programming, agar dapat dijadikan pedoman untuk memenuhi permintaan konsumen dengan menggunakan program aplikasi komputer.

\section{B. LANDASAN TEORI}

\section{Konsep Dasar Sistem}

Istilah system sebagaimana dinyatakan oleh Tatang M. Amirin system berasal dari bahasa Yunani "systema". Pengertian systema ini, selanjutnya diartikan oleh Shrode dan Voich, 1974 serta Elias M Award, 1979 sebagai berikut:

- Suatu keseluruhan yang tersusun dari sekian banyak bagian.

- Hubungan yang berlangsung diantara satuansatuan atau komponen secara teratur.

Definisi system dari Murdick dan Ross telah memerinci lebih banyak mengenai karakteristik system, antara lain yang tercakup dalam definisi yaitu :
1. Adanya unsur-unsur system yang terpadu.

2. Adanya tujuan yang hendak dicapai.

3. Adanya kegiatan yang dilakukan oleh system.

4. Adanya sesuatu yang diolah atau diproses oleh system.

5. Adanya sesuatu hasil yang dibuat oleh system.

Linier Programing ( LP ) adalah suatu cara untuk menyelesaikan persoalan pengalokasian sumbersumber yang terbatas di antara beberapa aktivitas yang bersaing, dengan cara yang terbaik yang mungkin dilakukan.

\section{Perencanaan Agregat (Aggregate Planning)}

Menurut T.Tani Handoko (1984, hal 234) perencanaan Agregat adalah proses perencanaan kuantitas dan pengeturan waktu keluaran selama periode waktu tertentu (biasanya antara 3 (tiga) bulan sampai 1(satu) tahun) melalui penyusunan variabel tingkat produksi, karyawan, dan variabel-variabel yang dapat dikendalikan lainnya.

\section{Jadwal Induk Produksi (Master Production Schedule)}

Merupakan gambaran atas periode perencanaan dari suatu permintaan termasuk ramalan, rencana penawaran, persediaan akhir, dan kuantitas yang dijanjikan tersedia atau suatu pernyataan mengenai produk apa yang akan dibuat, berapa jumlahnya serta kapan akan dibuat. Jadwal Induk Produksi (Master Production Schedule) harus dibuat secara realitas dengan mempertimbangkan kapasitas produksi, tenaga kerja maupun sub contract. 


\section{METODE}

\section{Data Penjualan Kaca}

Data penjualan kaca berdasarkan jenisnya untuk bulan April 2001 - Maret 2002

\section{Kapasitas Kerja Sistem Produksi}

Senin - Sabtu : - 8 jam Reguler / shift

\section{- 3 Jam Lembur/shift}

Untuk mengetahui besarnya jam orang yang dibutuhkan untuk membuat satu unit produk dihitung sebagai berikut :

Jumlah tenaga kerja $\mathrm{x}$ jam kerja dibagi rata-rata jumlah produk yang dihasilkan dalam satu unit / hari.

\section{Kapasitas Jam Mesin Produk ( Jam )}

Dari bagian produksi diketahui bahwa efisiensi mesin untuk produk $\mathrm{KC}-\mathrm{AB}, \mathrm{KC}-\mathrm{AC}$, KR-01，KR-03 adalah $85 \%$. Sedangkan 4 produk itu dihasilkan rata-rata per hari adalah sebagai berikut :

\section{Produk KC-AB}

Rata-rata produk perhari $=100$ unit

$85 \% \times 100=85$ unit $/$ hari

$$
\frac{85}{8}=10,63 \text { unit } / \text { jam }
$$

Sehingga dapat diperoleh jam mesin/unit

$$
\frac{1}{10.63}=0,094 \mathrm{jam} / \text { unit }
$$

\section{Produk KC-AC}

$$
\frac{1}{11.75}=0,085 \mathrm{jam} / \text { unit }
$$

\section{Produk KR-01}

$$
\frac{1}{10.63}=0,094 \mathrm{jam} / \text { unit }
$$

\section{Produk KR-03}

$$
\frac{1}{11,25}=0,089 \mathrm{jam} / \mathrm{unit}
$$

Harga pokok produksi per unit ( jam ) dihasilkan dari kapasitas kerja sistem produksi $\mathrm{x}$ biaya tenaga kerja / jam.

Biaya tenaga kerja Reguler : : Rp. 1.650

Biaya tenaga kerja Lembur $\quad$ : Rp. 2.300

\section{Kapasitas Produksi}

Pihak perusahaan sudah mempunyai ketetapan kapasitas produksi maksimal perharinya yaitu diperoleh dari, hari kerja $\mathrm{x}$ hari kerja reguler ( 8 jam per hari ), serta untuk lembur (3 jam per hari).

\section{Kebijaksanaan Perusahaan}

Perusahaan telah menetapkan berbagai kebijaksanaan yang menyangkut sasaran dalam standart pencapaian yang ditargetkan dalam setiap periode perencanaan. Secara umum perusahaan menetapkan sasaran sebagai berikut :

1. Pencapaian Minimasi Biaya Produksi Target minimasi biaya produksi ditetapkan untuk seluruh periode perencanaan dihitung dari total biaya operasi merupakan perkalian antara biaya operasi reguler dan lembur per unit yang dipakai untuk memproduksi masing-masing jenis barang. Perhitungan target minimasi biaya produksi yang ditetapkan perusahaan untuk 6 bulan periode perencanaan yang akan datang adalah : Rp. 680.590.700,--

2. Meminimalkan Total Biaya Penyimpanan Biaya penyimpanan harus diusahakan sekecil mungkin dengan memperhatikan kepentingan-kepentingan sasaran lainnya. Untuk mencapai tujuan yang diiginkan maka perusahaan menetapkan target penyimpanan 
dikarenakan perusahaan disamping punya target produksi, pihak perusahaan juga punya target penyimpanan yang ada digudang untuk melayani pesanan. Untuk pencapaian biaya total penyimpanan selama 6 bulan perencanaan yang diperoleh nantinya merupakan nilai minimum yang bisa dicapai

\section{ANALISA}

\section{Jadwal Induk Produksi}

Setelah perencanaan agregat dibuat, maka hasilnya di-disagregasikan kedalam kebutuhan-kebutuhan berdasarkan tahapan waktu untuk masing-masing jenis produk (individual products). Perencanaan ini disebut Jadwal Induk Produksi (Master Production Schedule, MPS). MPS biasanya menunjukkan kebutuhan produksi mingguan selama periode waktu antara 6 sampai 12 bulan. MPS bukan merupakan peramalan, tetapi lebih merupakan suatu jadwal yang berisikan informasi tentang "kapan" produksi harus diselesaikan

\section{Perencanaan Agregat}

Perencanaan agregat adalah penentuan jumlah dan waktu alokasi beberapa sumberdaya yang sifatnya tidak tetap seperti tenaga kerja dan persediaan guna memenuhi permintaan konsumen untuk jangka waktu menengah, yaitu antara 3 sampai 18 bulan yang akan datang. (Joko, 2001: 176)

\section{Konsep Algoritma Dan Pemrograman}

Salah satu konsep dasar yang digunakan dalam perancangan dan implementasi perangkat lunak adalah konsep bahwa sesuatu yang berukuran kecil itu indah (small is beautiful). Hal ini bukan berarti bahwa modul-modul yang membentuk suatu perangkat lunak dibuat sangat kecil. Data penjualan kaca berdasarkan jenisnya untuk bulan April-2001 Maret 2002 dapat dilihat pada tabel berikut :

Tabel 1. Data Penjualan Kaca Untuk Bulan April 2001 - Maret 2002 ( unit )

\begin{tabular}{|l|c|c|c|c|}
\hline \multirow{2}{*}{ Bulan } & \multicolumn{4}{|c|}{ Permintaan ( Dalam Unit ) } \\
\cline { 2 - 5 } & $\begin{array}{c}\text { KC- } \\
\text { AB }\end{array}$ & $\begin{array}{c}\text { KC- } \\
\text { AC }\end{array}$ & $\begin{array}{c}\text { KR- } \\
01\end{array}$ & $\begin{array}{c}\text { KR- } \\
03\end{array}$ \\
\hline April '01 & 2360 & 2349 & 2410 & 2400 \\
Mei '01 & 2396 & 2340 & 2420 & 2380 \\
Juni '01 & 2480 & 2465 & 2432 & 2390 \\
Juli '01 & 2500 & 2490 & 2485 & 2450 \\
Agst '01 & 2536 & 2583 & 2516 & 2477 \\
Sept '01 & 5272 & 2657 & 2548 & 2514 \\
Okt '01 & 2609 & 2741 & 2583 & 2548 \\
Nop '01 & 2644 & 2809 & 2615 & 2583 \\
Des '01 & 2682 & 2885 & 2649 & 2618 \\
Jan '02 & 2719 & 2958 & 2680 & 2652 \\
Feb '02 & 2670 & 2626 & 2640 & 2730 \\
Mar '02 & 2863 & 2952 & 2730 & 2673 \\
\hline
\end{tabular}

\section{Kapasitas Jam Mesin Produk ( Jam )}

Dari bagian produksi diketahui bahwa efisiensi mesin untuk produk KC-AB, KC-AC, KR-01, KR-03 adalah $85 \%$. Sedangkan 4 produk itu dihasilkan ratarata per hari adalah sebagai berikut :

\section{Produk KC-AB}

Rata-rata produk perhari $=100$ unit $85 \% \times 100=85$ unit $/$ hari

$$
\frac{85}{8}=10,63 \text { unit } / \text { jam }
$$


Sehingga dapat diperoleh jam mesin/unit

$$
\frac{1}{10.63}=0,094 \mathrm{jam} / \mathrm{unit}
$$

\section{Produk KC-AC}

$$
\frac{1}{11.75}=0,085 \mathrm{jam} / \mathrm{unit}
$$

\section{Produk KR-01}

$$
\frac{1}{10.63}=0,094 \mathrm{jam} / \mathrm{unit}
$$

\section{Produk KR-03}

$$
\frac{1}{11,25}=0,089 \mathrm{jam} / \mathrm{unit}
$$

Harga pokok produksi per unit ( jam ) dihasilkan dari kapasitas kerja sistem produksi $\mathrm{x}$ biaya tenaga kerja / jam.

\section{Kapasitas Produksi}

Semakin kecil ukuran suatu modul akan menyebabkan dibutuhkannya semakin banyak modul untuk membentuk suatu perangkat lunak secara utuh, sehingga menyebabkan kesulitan dalam melakkukan pengendalian pengeksekusian modul-modul yang ada.

Pihak perusahaan sudah mempunyai ketetapan kapasitas produksi maksimal perharinya yaitu diperoleh dari, hari kerja $\mathrm{x}$ hari kerja reguler ( 8 jam per hari ), serta untuk lembur (3 jam per hari).

\section{Pengembangan Model}

\section{Pengembangan}

model

telah menggambarkan hubungan antara variabelvariabel keputusan dengan parameter-parameter yang berkaitan serta target sasaran sesuai dengan kebijaksanaan perusahaan. Model tersebut telah dimasukkan dalam model penyelesaian Linear Programming, dimana perhitungan dilakukan dengan Komputer Program Visual Basic. Hasil pengolahan tersebut akan dibahas lebih lanjut pada bab V ini sebagai masukan utama dalam masalah pengambilan keputusan perencanaan produksi Agregat dan JIP kemudian di SIMkan pada PT. Serasa Purna Cipta, Sidoarjo.

\section{Hasil Penyelesaian Model}

Dari model yang telah dikembangkan yaitu model Linear Programming untuk perencanaan produksi agregat dan jadwal induk produksi dari bulan Mei - Oktober 2001 pada PT. Serasa Purna Cipta Sidoarjo diperoleh hasil penyelesaian yang dapat dilihat pada lampiran ( Solution Agregat). Hasil perhitungan tersebut diuraikan kembali pada penjelasan berikut ini :

\section{Perencanaan Produksi Agregat}

Hasil perencanaan produksi agregat pada PT. Serasa Purna Cipta Sidoarjo dengan menggunakan Linear Programming selama 6 bulan perencanaan dapat dilihat secara lengkap pada tabel berikut:

Tabel 2

Hasil Perhitungan Rencana Produksi Agregat PT. Serasa Purna Cipta Sidoarjo

Bulan April - September 2002

\begin{tabular}{|l|c|c|c|c|}
\hline Period & $\begin{array}{c}\text { Jenis } \\
\text { Produk }\end{array}$ & Permint & $\begin{array}{c}\text { Total } \\
\text { Produ } \\
\text { ksi }\end{array}$ & $\begin{array}{c}\text { Pers } \\
\text { ed }\end{array}$ \\
\hline April & KC - AB & 2648 & 2745 & 97 \\
& KC - AC & 2844 & 2939 & 95 \\
& KR - 01 & 2570 & 2668 & 98 \\
& KR - 03 & 2838 & 2644 & 93 \\
\hline
\end{tabular}




\begin{tabular}{|l|l|l|l|l|}
\hline Mei & KC - AB & 2838 & 2823 & 97 \\
& KC - AC & 3058 & 3058 & 95 \\
& KR - 01 & 2779 & 2779 & 98 \\
& KR - 03 & 2716 & 2716 & 93 \\
\hline Juni & KC - AB & 2823 & 2823 & 97 \\
& KC - AC & 3112 & 3112 & 95 \\
& KR - 01 & 2808 & 2808 & 98 \\
& KR - 03 & 2727 & 2727 & 93 \\
\hline Juli & KC - AB & 2823 & 2823 & 97 \\
& KC - AC & 3166 & 3166 & 95 \\
& KR - 01 & 2838 & 2838 & 98 \\
& KR - 03 & 2737 & 2737 & 93 \\
\hline Agst & KC - AB & 2823 & 2823 & 97 \\
& KC - AC & 3220 & 3220 & 95 \\
& KR - 01 & 2867 & 2867 & 98 \\
& KR - 03 & 2848 & 2848 & 93 \\
\hline Sept & KC - AB & 2823 & 2838 & 97 \\
& KC - AC & 3274 & 3274 & 95 \\
& KR - 01 & 2896 & 2896 & 98 \\
& KR - 03 & 2758 & 2758 & 93 \\
\hline
\end{tabular}

Seperti yang telah diuraikan pada bab sebelumnya pada model yang disusun terdapat keterkaitan antara permintaan, produksi dan persediaan produk pada setiap periode dengan periode berikutnya. Untuk lebih jelasnya dapat dilihat pada table sebagai berikut:

\section{Target Minimal Penyimpanan}

Merupakan hal yang sangat wajar apabila perusahaan menetapkan target penyimpanan dikarenakan perusahaan ini punya target produksi, pihak perusahaan juga punya target penyimpanan yang ada digudang untuk melayani pesanan, total penyimpanan 6 periode kedepan yaitu dapat dilihat pada tabel 4 berikut ini:

\section{Tabel 4}

Persediaan dan Target Minimal Persediaan Bulan per Unit

\begin{tabular}{|c|c|c|c|}
\hline Period & $\begin{array}{c}\text { Jenis } \\
\text { Produk }\end{array}$ & Persed & $\begin{array}{c}\text { Target } \\
\text { Minimal } \\
\text { Persediaan }\end{array}$ \\
\hline \multirow[t]{4}{*}{ April } & $\mathrm{KC}-\mathrm{AB}$ & 97 & 97 \\
\hline & $\mathrm{KC}-\mathrm{AC}$ & 95 & 95 \\
\hline & KR - 01 & 98 & 98 \\
\hline & KR - 03 & 93 & 93 \\
\hline \multirow[t]{4}{*}{ Mei } & $\mathrm{KC}-\mathrm{AB}$ & 97 & 97 \\
\hline & $\mathrm{KC}-\mathrm{AC}$ & 95 & 95 \\
\hline & $\mathrm{KR}-01$ & 98 & 98 \\
\hline & KR - 03 & 93 & 93 \\
\hline \multirow[t]{4}{*}{ Juni } & $\mathrm{KC}-\mathrm{AB}$ & 97 & 97 \\
\hline & $\mathrm{KC}-\mathrm{AC}$ & 95 & 95 \\
\hline & KR - 01 & 98 & 98 \\
\hline & KR - 03 & 93 & 93 \\
\hline \multirow[t]{4}{*}{ Juli } & $\mathrm{KC}-\mathrm{AB}$ & 97 & 97 \\
\hline & $\mathrm{KC}-\mathrm{AC}$ & 95 & 95 \\
\hline & KR - 01 & 98 & 98 \\
\hline & KR - 03 & 93 & 93 \\
\hline Agst & $\mathrm{KC}-\mathrm{AB}$ & 97 & 97 \\
\hline
\end{tabular}




\begin{tabular}{|c|c|c|c|}
\hline & KC - AC & 95 & 95 \\
& KR - 01 & 98 & 98 \\
& KR - 03 & 93 & 93 \\
\hline Sept & KC - AB & 97 & 97 \\
& KC - AC & 95 & 95 \\
& KR - 01 & 98 & 98 \\
& KR - 03 & 93 & 93 \\
\hline
\end{tabular}

\section{E. KESIMPULAN}

1. Hasil Peramalan Permintaan untuk 6 periode yang akan dating

\begin{tabular}{|c|c|c|c|}
\hline \multirow{2}{*}{$\begin{array}{c}\text { Jenis } \\
\text { Produk }\end{array}$} & \multicolumn{3}{|c|}{ Peramalan } \\
\cline { 2 - 4 } & April & Mei & Juni \\
\hline KC-AB & 2648 & 2823 & 2823 \\
KC-AC & 2844 & 3058 & 3112 \\
KR-01 & 2570 & 2779 & 2808 \\
KR-03 & 2551 & 2716 & 2737 \\
\hline Jenis & \multicolumn{3}{|c|}{ Peramalan } \\
Produk & Juli & Agst & Sept \\
\hline KC-AB & 2823 & 2823 & 2823 \\
KC-AC & 3166 & 3220 & 3274 \\
KR-01 & 2838 & 2867 & 2896 \\
KR-03 & 2737 & 2748 & 2758 \\
\hline
\end{tabular}

2. Dari hasil perhitungan dapat diketahui bahwa seluruh permintaan yang ada dapat terpenuhi dan tujuan yang ditetapkan dapat dicapai dengan tingkat minimasi biaya produksi sebesar Rp. 662.887 .110 dari tingkat minimasi biaya produksi sebesar Rp. 680.590.700, Jadi tingkat minimasi Rp. 17.703.590.
3. Hasil Sistem Informasi Manajemen

\begin{tabular}{|l|c|c|c|}
\hline \multirow{2}{*}{$\begin{array}{c}\text { Jenis } \\
\text { Produk }\end{array}$} & \multicolumn{3}{|c|}{ SIM untuk Reguler } \\
\cline { 2 - 4 } KC-AB & April & Mei & Juni \\
KC-AC & 2745 & 2823 & 2823 \\
KR-01 & 2668 & 3058 & 3112 \\
KR-03 & 2644 & 2779 & 2808 \\
\hline \multirow{2}{*}{ Jenis } & \multicolumn{3}{|c|}{ SIM untuk Reguler } \\
Produk & Juli & Agts & Sept \\
\cline { 2 - 4 } KC-AB & 2823 & 2823 & 2823 \\
KC-AC & 3166 & 3220 & 3274 \\
KR-01 & 2838 & 2867 & 2896 \\
KR-03 & 2737 & 2848 & 2758 \\
\hline
\end{tabular}

menjalankan program cukup kesulitan untuk pengoperasiaannya, akibatnya JIP sulit untuk diterapkan. Untuk mengatasi hal ini perlu diterapkan SIM untuk JIP pada masing-masing grup produk untuk tiap periodenya.

4. Jadwal Induk Produksi untuk 6 Bulan kedepan

\begin{tabular}{|l|l|c|c|c|c|c|}
\hline \multirow{2}{*}{$\begin{array}{l}\text { Jenis } \\
\text { Produk }\end{array}$} & \multicolumn{6}{|c|}{ JIP 6 Bulan Kedepan } \\
\cline { 2 - 7 } & April & Mei & Jun & Juli & Ag & Sep \\
st & $t$ \\
\hline KC-AB & 2842 & 292 & 292 & 292 & 292 & 292 \\
KC-AC & 3018 & 0 & 0 & 0 & 0 & 0 \\
KR-01 & 2766 & 315 & 320 & 326 & 331 & 336 \\
KR-03 & 2737 & 2 & 7 & 1 & 5 & 9 \\
& & 287 & 290 & 293 & 296 & 299 \\
& & 7 & 6 & 6 & 5 & 6 \\
& & 280 & 282 & 283 & 294 & 285 \\
& & 9 & 0 & 0 & 6 & 1 \\
\hline
\end{tabular}

Metode Linear Programming digunakan dikarenakan target perusahaan hanya satu tujuan prioritas adalah meminimasi biaya produksi. 
Program linier yang diterjemahkan dari Linier Programing ( LP ) adalah suatu cara untuk menyelesaikan persoalan pengalokasian sumber-sumber yang terbatas di antara beberapa aktivitas yang bersaing, dengan cara yang terbaik yang mungkin dilakukan.

\section{DAFTAR PUSTAKA}

Azis, M. Farid, Belajar Sendiri Pemrograman PHP 4, PT Elex Media Komputindo, Jakarta, 2001

Agung, Gregorius, Belajar Sendiri

Dreamweaver 3, PT Elex Media

Komputindo, Jakarta, 2001

\section{Badan Perencanaan Kabupaten Malang dan}

LPPM UWG Malang, Draft LA

Perencanaan Pembangunan Pertaniaan

Terpadu Studi Kelayakan Perencanaan

Pembangunan STA Kabupaten Malang, Malang, 2002

Indrajit, RE. Prastowo, Bambang N. dan Syukri, Muhammad, Aplikasi Web Database Menggunakan PHP \& MySQL, PT Elex Media Komputindo, Jakarta, 2002

Kadarsah, Suryadi dan Ramdhali, Ali, Sistem Pendukung Keputusan, Remaja Rosdakarya, Bandung, 1988

Kurniawan, Yahya, Aplikasi Web Database dengan PHP dan MySQL, PT Elex Media Komputindo, Jakarta, 2002

Mc. Leod, Jr, Sistem Infoemasi Manajemen, Edisi Bahasa Indonesia, Jilid II, PT. Prehalindo, Jakarta, 1991
Moekijat, Pengantar Sistem Infoemasi Manajemen, Remadja Karya CV, Bandung, 1988

Pemprov Jatim dan Kadinda dan FMA Jatim, Studi Kelayakan Penerapan Jaringan Usaha Dalam Rangka Pembentukan Pasar- Induk Agribisnis Di Jatim, 2001

Permadi, Analitycal Hierarkhi Process, PAU - EKUI, Jakarta, 1992

Saaty, Thomas L, Pengambilan Keputusan Bagi Para Pemimpin, Seri Manajemen no. 134, PT. Pustaka Binaman Pressindo, Jakarta, 1991

Sugiyono, Metode Penelitian Binsis, Cetakan kedua, CV. Alfa Beta, Bandung, 1991

Singarimbun, Masri dan Effendi, Sfian, Metode Penelitian Survai, LP3ES, Jakarta, 1992

Wahana Komputer Semarang, 10 Model Penelitian dan Pengolahannya dengan SPSS 10.01, Penerbit ANDI Yogyakarta, 2002

Davis B. Gordon, Pengantar Sistem Infoemasi Manajemen, PT. Pustaka Binaman P, Jakarta, 1991

Kadarsah, Suryadi dan Ramdhali, Ali, Sistem Pendukung Keputusan, Remaja Rosdakarya, Bandung, 1988

Mc. Leod, Jr, Sistem Infoemasi Manajemen, Edisi Bahasa Indonesia, Jilid I, PT. Prehalindo, Jakarta, 1991

Mc. Leod, Jr, Sistem Infoemasi Manajemen, Edisi Bahasa Indonesia, Jilid II, PT. Prehalindo, Jakarta, 1991

Moekijat, Pengantar Sistem Infoemasi Manajemen, Remadja Karya CV, Bandung, 1988

Mangkusubroto, Analisa Keputusan, Ganeca Exact, Bandung, 1992 
Murdicky, Robert G dan Ross, Clagett, Sistem Infoemasi Untuk Manajemen Modern, Edisi ketiga, Erlangga, Jakarta, 1986

Permadi, Analitycal Hierarkhi Process, PAU EK- UI, Jakarta, 1992

Siagian, Sistem Infoemasi Manajemen untuk Pengambilan Keputusan, Gunung Agung, Jakarta 1973

Saaty, Thomas L, Pengambilan Keputusan Bagi Para Pemimpin, Seri Manajemen no. 134, PT. Pustaka Binaman Pressindo, Jakarta, 1991

Sri Mulyono, Teori Pengambilan Keputusan, Edisi Revisi, Fakultas Ekonomi UI, Jakarta, 1996

Sugiyono, Metode Penelitian Binsis, Cetakan kedua, CV. Alfa Beta, Bandung, 1991

Singarimbun, Masri dan Effendi, Sofian, Metode Penelitian Survai, LP3ES, Jakarta, 1992 